\title{
Some Relations between Morphology and Physiology of Aspergillus Oryzae.
}

\author{
By Yoshio Otani. \\ From the Zymomycological Institute, the Impesial College of \\ Agriculture, Tottori, Japan. \\ (Received Feb. 17, 1939.) \\ INTRODUCTION.
}

Aspergillus Oryzae is a fungus which has an important part in brewing saké, shōchū (Japanese spirits), soy sauce and miso (soy bean paste). In 1878, Ahlburg(1) gave it the name Eurotium Oryzae. Later $\mathrm{Cohn}^{(2)}$ revised the name to Aspergillus Oryzae, which is the current term used now. But at that time, the morphological description was very simple, and was not sufficient to show the characteristics of this species. Later, Büsgen ${ }^{(3)}$ made a more careful study of the subject and showed the characteristics of this organism more clearly. Wehmer ${ }^{(4)}$ isolated a strain of this fungus, through the pure culture method, and made a careful study of it. Thus the micro-biological characteristics were first shown in detail. Also, Klöcker and Shiönning( ${ }^{(5)}$ found that this fungus produced sclerotia. Studies of the enzymes of this fungus have been made by Atkinson ${ }^{(6)}$; Kellner, Mori and Nagaoka ${ }^{(7)}$; Stone and Wreight. ${ }^{(8)}$ But a comparative study of the details of the morphological and physiological characteristics of the fungi, given in the studies made by these scholars, showed that there were a few points on which they disagreed. Takahashi $^{(9)}$ took some strains which he had isolated from moyashi (koji-flora) and made comparative experiments with these, and showed clearly that this species could be classified into a number of varieties. Oshima ${ }^{(10)}$ found that from the enzymatic standpoint, the fungus could be divided into some groups and the groups classified according to the degree of enzymatic action in each. Recently, Sakaguchi $^{(11)}$ classified them according to their ability to produce metabolic products, such as alcohol and various acids. $\mathrm{He}^{(12)}$ also made a classification, according to the colour and form of the mycelia of the fungus. Thus we see that Aspergillus Oryzae is only one species, but has in it groups which have some different characteristics.

The author has collected from various places, numerous strains of this fungus, and made a study of their morphology and physiology, trying to get a clearer knowledge of the relation between the two, the results of which are given below.

\section{Methods of Experiment and Observation.}

Morphological studies :- Various strains of Aspergillus Oryzae, were cultivated on koji-agar at the temperature of $30^{\circ} \mathrm{C}$, for two whole days, and the height of the mycelia mass, the diameter of the conidium, the length and diameter of the sterigma, the diameter of globule, the length and diameter of the conidiophore, 
and the width of the hyphae were examined both with the naked eye and under the microscope.

Physiological studies :- A study was made of the starch-decomposing power, protein decomposing power, the acid producing quality and the colour which was. shown. The essential points and the methods are as follows :- -

To measure the starch-decomposing power the medium was made through Peffer-solution, which has no cane sugar in it (the solution has $1 \%$ of ammonium nitrate, $0.5 \%$ of potassium bi-phosphate, $0.25 \%$ magnesium sulphate, a trace of iron chloride). Soluble starch was added as a carbon source in the following ratio, $i . e$., $0.7 \%, 1.4 \%, 2.2 \%, 3.2 \%, 5 \%$ and $8 \%$, and in these media the numerous strains of the fungi were inoculated. By the use of the iodine method, the degree of starch digested was noted day by day. If the strain had great power to decompose starch, when put into the incubator for 3 days, at the temperature of $30^{\circ} \mathrm{C}$, the starch in the $0.7 \%$ soluble starch medium was digested. In the medium which had $8 \%$ of starch, there was no strain which was powerful enough to change it. In the medium which had $5 \%$ starch, there were 7 strains which changed it to a blue-violet colour, through the reaction of iodine.

Koji-gelatine was used to measure the power to decompose protein. $20 \%$ of gelatine was put into the koji-extract, and allowed to congeal. And in this, as a medium, strains of Aspergillus Oryzae was inoculated, and was left at the room temperature (about $20^{\circ} \mathrm{C}$ ) for from three to five weeks.. The strain which had a strong protein decomposing power quickly liquefied the gelatine. Thus it could easily be seen that the medium divided itself into three parts, mycelia mass, the liquefied part, and the congealed part. When the liquefied part were seen to be large, it was clearly seen that the protein decomposing power was great.

To measure the acid producing power, koji-extract was used. In this medium the strains were inoculated, and were cultivated for fifty days. Finally $5 \mathrm{cc}$ of the metabolic solution was taken and was neutralized with $N_{/} 10 \mathrm{NaOH}$ solution, using phenolphthalein as an indicator. Through the amount titrated, the degree of acidity was determined.

The power to produce pigment was determined as follows:- the strains were inoculated into koji-extract or koji-agar, and cultivated for five weeks, and with the naked eye, the degrees of the developing dark brown colour were noted.

\section{Results of the Experiment and Discussion.}

Through these experiments, it was found that there are a great many minor differences in the various strains, both in their morphology and in their physiology. If these differences are minutely classified, from the enzymatic standpoint, both the starch-decomposer and the protein decomposer might be divided into two groups. In addition, from the metabolic standpoint, it may be divided into acidproducer and pigment producer. The author took five strains each from the strongest strains, and gave the averages of these strains in the following table :- 


\begin{tabular}{|c|c|c|c|c|}
\hline & \multicolumn{2}{|c|}{ Enzymatic classification } & \multicolumn{2}{|c|}{ Metabolic classification } \\
\hline & $\begin{array}{c}\text { Starch- } \\
\text { decomposer }\end{array}$ & $\begin{array}{l}\text { Protein- } \\
\text { decomposer }\end{array}$ & Acid-producer & $\begin{array}{l}\text { Pigment- } \\
\text { producer }\end{array}$ \\
\hline Height of mycelia mass $(\mathrm{mm})$ & 3.06 & 1.90 & 3.1 & 1.94 \\
\hline Diameter of conidium $(\mu)$ & $4.8 \sim 9.2$ & $4.3 \sim 7.2$ & $4.8 \sim 8.1$ & $4.6 \sim 7.7$ \\
\hline Steriama length $(\mu)$ & $13.9 \sim 27.6$ & $13.8 \sim 19.2$ & $15.1 \sim 23.4$ & $12.2 \sim 19.3$ \\
\hline diameter & $4.3 \sim 5.4$ & $3.8 \sim 5.2$ & $4.5 \sim 6.0$ & $4.8 \sim 6.0$ \\
\hline Diameter of sterigma $(\mu)$ & $22.0 \sim 39.9$ & $16.1 \sim 26.2$ & $19.2 \sim 26.9$ & $18.7 \sim 27.0$ \\
\hline length $(\mu)$ & $1.1 \sim 1.3$ & $0.5 \sim 0.6$ & $0.5 \sim 1.1$ & $0.5 \sim 1.0$ \\
\hline Idiameter $(\mu)$ & $8.3 \sim 13.2$ & $5.8 \sim 11.0$ & $7.0 \sim 12.9$ & $6.1 \sim 10.6$ \\
\hline Width of hyphae $(\mu)$ & $3.5 \sim 9.0$ & $4.9 \sim 8.9$ & $3.8 \sim 11.2$ & $3.3 \sim 10.8$ \\
\hline Decumposition of starch & ++ \pm & \pm & + & - \\
\hline Decomposition of protein & \pm & $++t \pm$ & \pm & + \\
\hline Production of acid (cc) & 3.28 & 2.84 & 5.73 & 2.17 \\
\hline Pigment formation & \pm & \pm & + \pm & +++ \\
\hline
\end{tabular}

Note : $-\quad-=0, \pm=$ few, $+=$ the relative amount (indicated by the number of + ).

As shown in the foregoing table, the greatest morphological difference shown was the height of the mycelia mass. The next greatest difference was in the diameter of the globules and in the length and diameter of the conidiophore. Comparing the morphological differences and the physiological differences, it was found that there was a direct relation between the starch-decomposing power and the protein-decomposing power, between the acid-producing power and pigmentproducing power.

For example, there are many points of similarity, between the starch decomposer and the acid producer, in the following points :- the height of the mycelia, the diameter of the globules and the length and diameter of the conidiophore. Also the protein decomposer and the pigment producer were found to be very similar, in the morphology of the three parts mentioned above. From the physiological point of view, in the starch decomposer and in the acid producer, the starch-decomposing power and the acid producing power were found to be great. In the protein decomposer and in the pigment producer, the protein decomposing power was great. But in pigment production, the above mentioned relations did not hold good. So this side of the subject must be studied somewhat more thoroughly.

From the above facts, both the starch decomposer and the acid producer have an effect on carbohydrates. With regard to this, both the protein decomposer and the pigment producer seem to have an effect on the protein and its decomposition products. But the mechanism by which the dark brown colour appears in the Aspergillus Oryzae culture is not yet clearly understood, nor is the real construction of the pigment yet understood. So the author is not yet able to state any clear solution beyond that the above facts were noticed. In the various strains which the author used, there are some which seem to have both characters and 
[Vol. 15,

there are some which seem to have a character between the two. But such variations seem to be a general characteristic of any micro-organism.

\section{Summary.}

The author made a number of comparative experiments with regard to the morphology and physiology of various strains of Aspergillus Oryzae. The enzymatic characteristics may be divided into two, i. e., starch decomposer and protein decomposer. There were two characteristics of the metabolic product, i.e., acid producer and pigment producer. The morphology and physiology of the starch decomposer and the acid producer were very similar. Those of the protein decomposer and pigment producer were also very similar. Thus, we were able to place the starch decomposer and the acid producer in one group which has the power to act on carbohydrates. Both the protein decomposer and the pigment producer were classified in the other group which acts on protein and on its decomposition products. In addition, among the various strains, there were some which were between the two classes mentioned above, and there were some which had the characteristics of both groups.

\section{Bibliography}

(1) Ahlburg \& S. Matsubara: Tokyo Ijishinshi, 24, 12 (1878)

(2) F. Cohn: Jahresber. schles. Gesell.' vaterl. Cultur, 61 (1883), 226 (1884)

(3) M. Büsgen: Ber. d. deutsch. Bot. Ges. 3, Generalvers. 66 (1885)

(4) C. Wehmer: Centralbl. Bakt., II, 1, 150 u. 209 (1895)

(5) A. Klöcker, u. H. Schiönning: Centralbl. Bakt., II, 1, 782 (1895)

(6) R. W. Atkinson: Memoir. Tukyo Imp. Univ. Sc. Dept., 6, 1 (1881)

(7) O. Kellner, Y. Mori, u. M. Nagaoka: Ztschr. f. phys. Chem., 14, 297 (1890)

(8) W. E. Stone \& H. E. Wreight: J. Amer. Chem. Soc., 20, 637 (1898)

(9) T. Takahashi: Jōzōshikenjo-Hōkoku, 12, 121 (1906), 37, (1911)

(10) K. Oshima: J. Coll. Agr. Hokkaidu Imp. Univ., 19, 135 (1928)

(11) K. Sakazuchi : Jōzōgaku-Zasshi, 8, 241 (1930), 10, 16 (1932)

(12) K. Sakaguchi : Jōzōronbunshū, III, 247 (1933) 